\title{
Predictive and prognostic factors in second- and third-line erlotinib treatment in NSCLC patients with known status of the $E G F R$ gene
}

\author{
PAWEŁ KRAWCZYK ${ }^{1}$, DARIUSZ M. KOWALSKI ${ }^{2}$, KAMILA WOJAS KRAWCZYK ${ }^{1}$, \\ MICHAŁ SZCZYREK ${ }^{1,3}$, RADOSŁAW MLAK ${ }^{1}$, ANDRZEJ ROLSKI ${ }^{1}$, ANETA SZUDY ${ }^{1}$, ROBERT KIESZKO ${ }^{1}$, \\ KINGA WINIARCZYK $^{2}$, JANUSZ MILANOWSKI ${ }^{1,4}$ and MACIEJ KRZAKOWSKI ${ }^{2}$ \\ ${ }^{1}$ Department of Pneumonology, Oncology and Allergology, Medical University of Lublin, Lublin; \\ ${ }^{2}$ Department of Lung Cancer and Chest Tumours, Maria Sklodowska-Curie Memorial Cancer Centre and \\ Institute of Oncology, Warsaw; ${ }^{3}$ Chair of Internal Medicine and Department of Internal Medicine in Nursing, \\ Medical University of Lublin, Lublin; ${ }^{4}$ Institute of Rural Health in Lublin, Lublin, Poland
}

Received March 11, 2013; Accepted May 14, 2013

DOI: $10.3892 /$ or.2013.2553

\begin{abstract}
Erlotinib is a reversible tyrosine kinase inhibitor of epidermal growth factor receptor (TKI EGFR). In Poland, as of July 2012, it is used in the treatment only of patients with non-small cell lung cancer (NSCLC) and with EGFR mutation gene after standard chemotherapy failure. The effectiveness of erlotinib in second- or third-line treatment of NSCLC patients without $E G F R$ activating mutation gene remains debatable. Clinical trial results indicated that TKI EGFR showed an efficacy of $70-80 \%$ in patients with EGFR mutations, while the clinical response to treatment among unselected Caucasian patients is only $10 \%$. The present study was conducted in a group of 71 patients with inoperable, locally advanced or metastatic NSCLC treated with erlotinib as the second- or third-line therapy. Molecular tests (examination of EGFR mutation and gene amplification) were carried out retrospectively. Objective response rate, overall survival (OS) and progression-free survival (PFS) were calculated. Effects of clinical and molecular factors including the presence of EGFR mutations, EGFR gene amplification, patient performance status, rash, smoking status, time from diagnosis to start of therapy, weight loss and the serum LDH levels were analyzed. An objective response in the form of partial response occurred in only 5 patients $(7 \%)$, who carried EGFR gene mutation. Median time to PFS for the entire group of patients was 1.5 months and median OS was 10 months. The strongest factors increasing the risk of progression in patients treated with erlotinib were the absence
\end{abstract}

Correspondence to: Professor Paweł Krawczyk, Department of Pneumonology, Oncology and Allergology, Medical University of Lublin, Jaczewskiego 8, 20-950 Lublin, Poland

E-mail:krapa@poczta.onet.pl

Key words: erlotinib, non-small cell lung cancer, EGFR mutation of activating mutations in the EGFR gene (6-fold increased risk) and no treatment-related rash (4.5-fold increased risk). The most important factors affecting the risk of early mortality were poor performance status (HR 37.344; P>0.0001), no treatment-related rash $(\mathrm{HR} 14.9348 ; \mathrm{P}=0.0002)$ and a short response time on the first-line chemotherapy (HR 9.519; $\mathrm{P}=0.0445)$.

\section{Introduction}

Lung cancer is the most common malignancy in humans. It is also the most common cause of cancer-related mortality among both men and women in most developed countries. Approximately $85 \%$ of cases involve non-small cell lung cancer (NSCLC), which generally has the histological structure of squamous cell carcinoma or adenocarcinoma $(1,2)$. Surgery, chemotherapy and radiotherapy remain the standard of treatment in NSCLC. Despite the development of various methods of treatment, NSCLC is still associated with very poor prognosis. Only $10-15 \%$ of patients survive 5 years from diagnosis. Metastatic NSCLC is fatal in $100 \%$ of cases (2).

Progress in understanding the biology of cancer leads to personalization of therapy and introduction of drugs aimed at blocking defective metabolic pathways of cancer cells. Erlotinib is an example of a drug with a molecular mechanism of action, which is currently used in the treatment of patients with NSCLC. It is a reversible small molecule tyrosine kinase inhibitor of epidermal growth factor receptor (TKI EGFR). EGFR abnormalities such as strong EGFR protein expression, high polysomy or amplification and EGFR gene mutations are relatively common in NSCLC. Kinase inhibition stops cancerous cells in the G1 phase of the cell cycle and induces apoptosis, which leads to a decrease of proliferation and reduces the capacity for invasion and metastasis (3).

The aim of the present study was to determine the prognostic and predictive factors in second- and third-line erlotinib therapy in NSCLC patients with known status of EGFR gene mutation. 


\section{Materials and methods}

Patient characteristics. This study presents results of research that was conducted in a group of 71 patients (36 men and 35 women) with inoperable, locally advanced and metastatic NSCLC treated with second- or third-line erlotinib in the period between 2008 and 2011. The study group consisted of

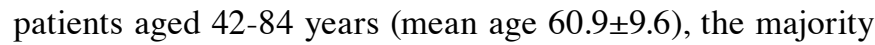
$(\mathrm{n}=59,83.1 \%)$ current or ex-smokers. Adenocarcinoma was diagnosed in $57 \%$ of tumors. Qualification for erlotinib was based on radiologically confirmed progression after first-line chemotherapy in patients with documented first-line response, without rapid deterioration of performance status and weight loss. The clinical characteristics of the study group are presented in Table I.

Criteria for assessing the effects of treatment (treatment response, disease stabilization or progression) were based mainly on the analysis of images from spiral computed tomography (CT) of the chest and sites suspected of metastases and were consistent with the RECIST 1.1 guidelines. The criteria for anemia and non-hematological complications were based on the Common Toxicity Criteria (CTC) v.6.0 guidelines. Patient performance status was assessed according to the ECOG-WHO score.

Examination of EGFR gene abnormalities. Patients were qualified for treatment without taking molecular factors into consideration; molecular tests were carried out retrospectively after completion of treatment. EGFR expression was determined by immunohistochemistry (IHC) using monoclonal antibody from Dako (Denmark). The fluorescence in situ hybridization (FISH) method was used to assess amplification of the EGFR gene using molecular probes for Abbott Molecular (USA). The presence of exon 19 deletions was examined using the PCR technique and the amplified PCR product fragment length analysis. In order to evaluate the L858R substitutions in exon 21, the ASP-PCR (allele-specific PCR) technique was used along with two pairs of PCR primers. PCR primers were marked with Cy5 fluorochrome. The results were analyzed on an ALF Express II sequencer. The direct sequencing by the Sanger method for $E G F R$ gene mutation detection was also used.

Statistical analysis. For statistical analysis we used the Chi-square test to compare the quantity of patients with different response to treatment and survival, depending on the prevalence of selected predictive and prognostic factors. This test was also used to compare the number of patients with and without $E G F R$ gene mutation in different subgroups of age, gender, histopathological diagnosis and smoking status. To compare the probability of survival and progression between the groups with different clinical and molecular factors, the Kaplan-Meier method was used. Cox regression model with 'step by step' selection was used to determine the influence of clinical and molecular factors on overall survival (OS) of patients treated with erlotinib.

\section{Results}

Estimation of EGFR gene abnormalities. Seventeen activating mutations were detected in the EGFR gene (24\%), including
Table I. Clinical characteristics of the study group.

\begin{tabular}{|c|c|}
\hline Factor & $\mathrm{n}(\%)$ \\
\hline \multicolumn{2}{|l|}{ Gender } \\
\hline Male & $36(50.7)$ \\
\hline Female & $35(49.3)$ \\
\hline \multicolumn{2}{|l|}{ Age (years) } \\
\hline Median & 61 \\
\hline Mean \pm SD & $60.9 \pm 9.6$ \\
\hline Range & $42-84$ \\
\hline \multicolumn{2}{|l|}{ Smoking status } \\
\hline Current and ex-smokers & $59(83.1)$ \\
\hline Pack-years (median; mean \pm SD) & $3131.3 \pm 22.4$ \\
\hline Non-smokers & $12(16.9)$ \\
\hline \multicolumn{2}{|l|}{ Histological diagnosis } \\
\hline Adenocarcinoma & $41(57.7)$ \\
\hline Squamous cell carcinoma & $18(25.3)$ \\
\hline Adenosquamous carcinoma & $2(2.8)$ \\
\hline Large cell carcinoma & $7 \quad(9.9)$ \\
\hline NSCLC NOS & $3(14.3)$ \\
\hline \multicolumn{2}{|l|}{ Stage } \\
\hline IIIA & $11(15.5)$ \\
\hline IIIB & $20(28.2)$ \\
\hline IV & $40(56.3)$ \\
\hline \multicolumn{2}{|l|}{ First-line chemotherapy } \\
\hline Cisplatin (or carboplatin) + vinorelbine & $39(54.9)$ \\
\hline Cisplatin (or carboplatin) + gemcitabine & $16(22.6)$ \\
\hline Cisplatin + pemetrexet & $5(7.1)$ \\
\hline $\begin{array}{l}\text { Cisplatin (or carboplatin) + taxans } \\
\text { (docetaxel or paclitaxel) }\end{array}$ & $3(4.2)$ \\
\hline Vinorelbine monotherapy & $4(5.6)$ \\
\hline Other (including carboplatin + etoposide) & $4(5.6)$ \\
\hline \multicolumn{2}{|l|}{ Radiotherapy } \\
\hline Yes & $31(43.7)$ \\
\hline No & $40(56.3)$ \\
\hline \multicolumn{2}{|l|}{ Prior surgical treatment } \\
\hline Yes & 17 (23.9) \\
\hline No & $54(76.1)$ \\
\hline
\end{tabular}

SD, standard deviation; NSCLC, non-small cell lung cancer; NOS, not otherwise specified.

12 deletions in exon 19 (70.6\% of all identified mutations including three rare deletions) and 5 L858R substitutions in exon 21 (19.4\% of all identified mutations). Amplification of the EGFR gene in the tumor cells was observed in 29 patients ( $40.8 \%$, a positive FISH test), and normal number of copies of the EGFR gene in 10 patients (14.1\%, a negative FISH test). In 32 patients (45.1\%) FISH testing either gave unreliable results or could not be performed due to the limited histological material. EGFR gene activating mutations occurred with similar frequency in the groups of patients with or without $E G F R$ gene amplification detected by FISH, and in groups of patients with 
Table II. Characteristics of patients in relation to the status of EGFR gene.

\begin{tabular}{|c|c|c|c|c|c|c|}
\hline Factor & $\begin{array}{l}\text { Wild-type } \\
E G F R \text { gene } \\
\text { n }(\%)\end{array}$ & $\begin{array}{l}\text { Mutation in } \\
E G F R \text { gene } \\
\mathrm{n}(\%)\end{array}$ & P-value & $\chi^{2}$ & $\begin{array}{l}\text { Deletion in } \\
\text { exon } 19 \\
\text { n }(\%)\end{array}$ & $\begin{array}{c}\text { L858R } \\
\text { substitution } \\
\text { in exon } 21 \\
\mathrm{n}(\%)\end{array}$ \\
\hline Study group & $54(76)$ & $17(24)$ & & & $12(16.9)$ & $5(7.1)$ \\
\hline Gender & & & 0.083 & 3.012 & & \\
\hline Male & $31 \quad(86.1)$ & $5(13.9)$ & & & $4(11.1)$ & $1 \quad(2.8)$ \\
\hline Female & $23(65.7)$ & $12(34.3)$ & & & $8(22.9)$ & $4(11.4)$ \\
\hline Age (years) & & & 0.26 & 1.267 & & \\
\hline$<65$ & $31 \quad(70.4)$ & $13(29.6)$ & & & $8(18.2)$ & $5(11.4)$ \\
\hline$\geq 65$ & $23(85.2)$ & $4(14.8)$ & & & $4(14.8)$ & $0 \quad(0)$ \\
\hline Smoking status & & & 0.0006 & 11.788 & & \\
\hline Smokers & $50 \quad(84.7)$ & $9(15.3)$ & & & $5(8.5)$ & $4(6.8)$ \\
\hline Non-smokers & $4 \quad(33.3)$ & $8(66.7)$ & & & $7(58.4)$ & $1 \quad(8.3)$ \\
\hline Histological diagnosis & & & 0.299 & 4.88 & & \\
\hline Adenocarcinoma & $30 \quad(73.2)$ & $11(26.8)$ & & & $8(19.5)$ & $3(7.3)$ \\
\hline Squamous-cell carcinoma & $16(88.9)$ & $2(11.1)$ & & & $2(11.1)$ & $0 \quad(0)$ \\
\hline Adenosquamous carcinoma & $1(50)$ & $1(50)$ & & & $1(50)$ & $0 \quad(0)$ \\
\hline Large-cell carcinoma & $4 \quad(57.1)$ & $3(42.9)$ & & & $1(14.3)$ & $2(28.6)$ \\
\hline NSCLC NOS & $3(100)$ & $0 \quad(0)$ & & & $0(0)$ & $0 \quad(0)$ \\
\hline$E G F R$ gene amplification & & & 0.419 & 1.739 & & \\
\hline Yes (positive FISH result) & $24 \quad(82.8)$ & $5(17.2)$ & & & $4(13.8)$ & $1(3.4)$ \\
\hline No (negative FISH result) & $8(80)$ & $2(20)$ & & & $2(20)$ & $0 \quad(0)$ \\
\hline No FISH result available & $22(68.75)$ & $10(31.25)$ & & & $6(18.75)$ & $4(12.5)$ \\
\hline Erlotinib treatment-related rash & & & 0.193 & 1.69 & & \\
\hline Yes & $9(60)$ & $6(40)$ & & & $5(33.3)$ & $1(6.7)$ \\
\hline No & $45 \quad(80.4)$ & $11(19.6)$ & & & $7(12.5)$ & $4(7.1)$ \\
\hline Response to first-line treatment & & & 0.157 & 2.002 & $11(21.6)$ & $4(7.8)$ \\
\hline $\mathrm{CR}, \mathrm{PR}, \mathrm{SD}$ & 36 (70.6) & $15(29.4)$ & & & $1(5)$ & $1(5)$ \\
\hline PD & $18(90)$ & $2(10)$ & & & & \\
\hline Time of response to first-line treatment (months) & & & 0.918 & 0.011 & & \\
\hline$\leq 12$ & $45 \quad(75)$ & $15(25)$ & & & $10(16.7)$ & $5(8.3)$ \\
\hline$>12$ & $9(81.8)$ & $2(18.2)$ & & & $2(18.2)$ & $0(0)$ \\
\hline Loss of body mass in 3 months & & & 0.997 & 0 & & \\
\hline$\leq 5 \%$ & $37(77.1)$ & $11(22.9)$ & & & $8(16.65)$ & $3(6.25)$ \\
\hline$>5 \%$ & 17 (73.9) & $6(26.1)$ & & & $4(17.4)$ & $2(8.7)$ \\
\hline Time from diagnosis to erlotinib treatment (months) & & & 0.859 & 0.032 & & \\
\hline$\leq 12$ & 31 (75.6) & $10(24.4)$ & & & $6(14.6)$ & $4(9.8)$ \\
\hline$>12$ & $23(76.7)$ & $7(23.3)$ & & & $6(20)$ & $1(3.3)$ \\
\hline
\end{tabular}

EGFR, epidermal growth factor receptor; NSCLC, non-small cell lung cancer; NOS, not otherwise specified; FISH, fluorescent in situ hybridization; CR, complete response; PR, partial response; PD, progressive disease; SD, stable disease.

both presence and absence of EGFR expression on the cell surface detected by IHC.

The incidence of mutations was slightly higher among women $(n=12,34.3 \%)$ than among men $(n=5,13.9 \%)$ and did not depend on age. EGFR activating mutations were significantly more frequent in non-smoking patients $(n=8,66.7 \%)$ than in former or current smokers $(n=9,15.3 \%)$. The number of mutations in patients with adenocarcinoma and non-adenocarcinomas did not differ significantly. The incidence of grade 3-4 rash after erlotinib treatment was not significantly associated with the presence of EGFR gene activating mutations. It should be noted, however, that rash as a result of TKI EGFR therapy occurred slightly more often in patients with EGFR mutations (Table II), as well as in patients with EGFR gene amplification. 


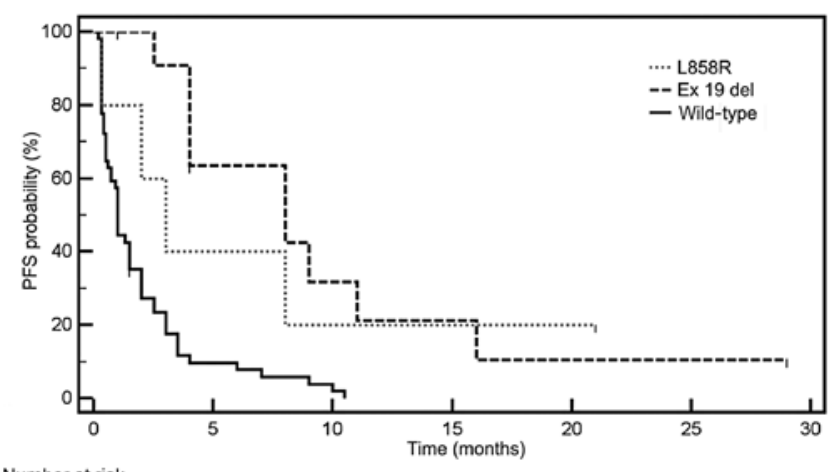

Number at risk

$\begin{array}{rrrrrrrr}\text { Wild-type } & 54 & 5 & 1 & 0 & 0 & 0 & 0 \\ \text { Ex 19 del } & 12 & 6 & 3 & 2 & 1 & 1 & 0 \\ \text { L858R } & 5 & 2 & 1 & 1 & 1 & 0 & 0\end{array}$

Figure 1. Impact of EGFR gene mutations on the progression-free survival (PFS) in patients treated with erlotinib.

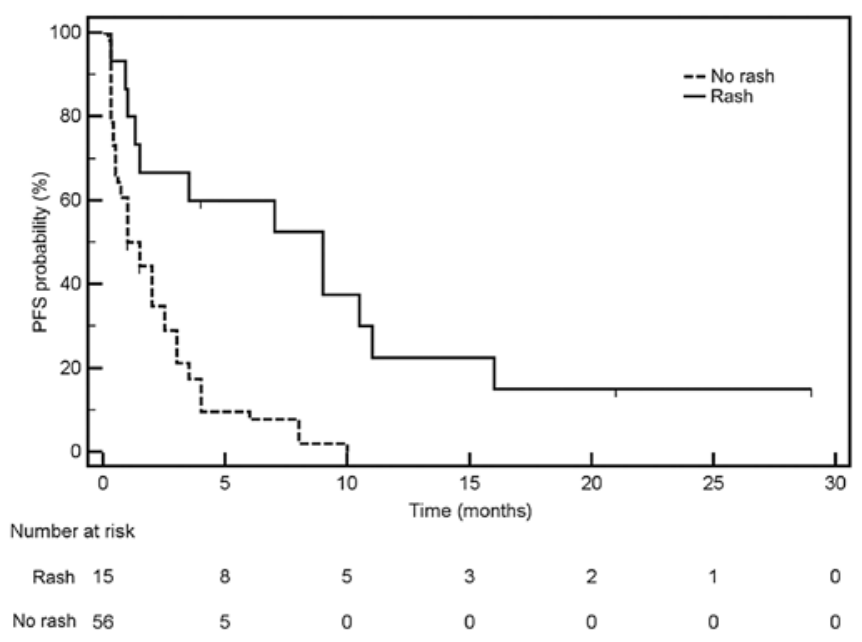

Figure 2. The relationship between the occurrence of treatment-related rash and progression-free survival (PFS) in patients treated with erlotinib.

Although the response to first-line chemotherapy with platinum compounds was slightly more frequent in patients with EGFR mutations, the length of response and the time from diagnosis to start of erlotinib did not depend on the presence of the mutation. There was no significant relationship between the presence of EGFR mutation and loss of body mass.

Estimation of response to erlotinib treatment. An objective response to erlotinib treatment in the form of partial response (PR) occurred in only 5 patients (7\%), including 3 second-line and 2 third-line patients. Duration of remission in relation to clinical characteristics of patients were: i) 4 months (observation cut-off) in a smoking (30 pack-years) 53-year-old woman with large-cell carcinoma and a deletion in exon 19 of the EGFR gene; ii) 8 months in a smoking (31 pack-years) 52-year-old man with large-cell carcinoma and mutation in exon 21 of the EGFR gene; iii) 9 months in a smoking (10 pack-years) 46-year-old man with adenocarcinoma and a deletion in exon 19 of the EGFR gene; iv) 16 months in a non-smoking 60 -year-old woman with adenosquamous cell carcinoma and deletion in exon 19 of the EGFR gene and EGFR gene

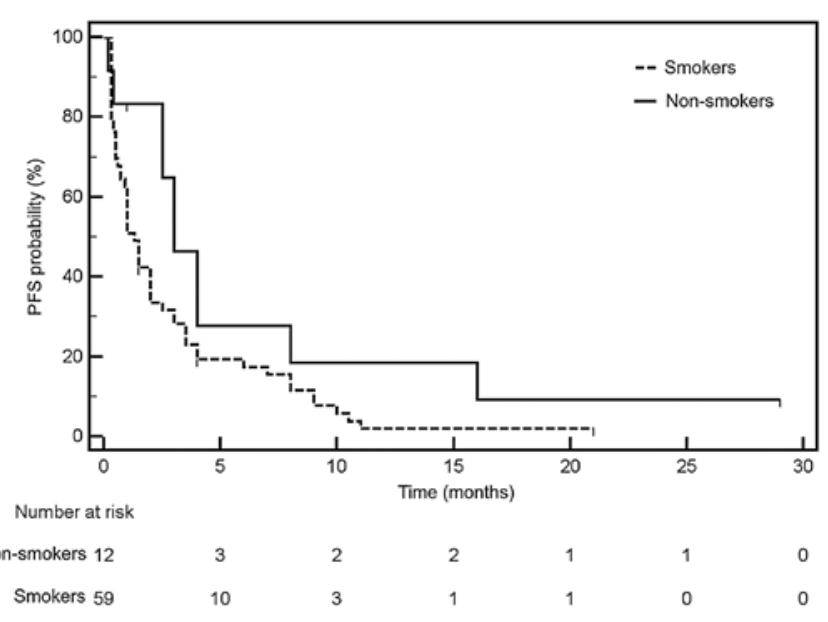

Figure 3. Impact of smoking status on progression-free survival (PFS) in patients treated with erlotinib.

amplification (84\% of tumor cells with abnormal number of EGFR gene copies); v) 29 months (observation cut-off) in a non-smoking 74-year-old man with adenocarcinoma and a deletion in exon 19 of the EGFR gene. It should be noted that in all cases of PR as a result of erlotinib treatment activating mutation in the EGFR gene was present in tumor cells, and that all patients with PR suffered a rash of varying severity.

Stable disease (SD) during treatment with erlotinib in second- or third-line occurred in 24 patients $(33.8 \%)$, including 9 patients with activating EGFR mutations $(37.5 \%$ of all patients with SD). Three patients with rare deletions in exon 19 of the EGFR gene achieved SD lasting 8 ( $\triangle \mathrm{L} 747-\mathrm{P} 753)$, 8 ( $\triangle$ E746-S752) and 4 months ( $\triangle$ E746-P753).

Progressive disease (PD) during erlotinib treatment occurred in 42 patients $(59.2 \%)$, of which only 3 had EGFR activating mutations (7.1\% of all patients with PD); two cases with L858R substitution and one patient with deletion in exon 19.

Absence of mutation in the EGFR gene was the strongest independent factor increasing the percentage of early progression in patients treated with erlotinib $\left(\mathrm{P}=0.0002, \chi^{2}=13.76\right)$. Other factors that increased the incidence of progression during erlotinib therapy were: short response to first-line chemotherapy, high serum LDH level and the absence of a rash associated with erlotinib treatment. Notably, the progression or stabilization of disease did not depended on gender, age, smoking status (there were only 12 non-smokers in the group), pathological diagnosis and amplification of EGFR gene. Patients with poorer performance status, weight loss and anemia had only slightly decreased response rate compared to patients without these adverse prognostic factors (Table III).

The median progression-free survival (PFS) for the entire group of patients treated with erlotinib was 1.5 months. The study, however, had a considerable weakness resulting from the large number of incomplete observations $(n=41)$. Observations in this group were carried out at least until the end of erlotinib therapy. Median PFS was significantly longer in patients with EGFR activating mutations $(\mathrm{HR}=0.309 ; 95 \% \mathrm{CI}, 0.19-0.503)$ (Fig. 1) and in patients with rash associated with erlotinib (Fig. 2) as compared to patients without those factors. However, the median PFS was not the same in all carriers of EGFR gene 
Table III. Clinical and molecular factors influencing the risk of early progression in patients treated with erlotinib.

\begin{tabular}{|c|c|c|c|c|c|}
\hline Factor & $\begin{array}{l}\text { Total } \\
\mathrm{n}(\%)\end{array}$ & $\begin{array}{c}\text { PD } \\
\mathrm{n}(\%)\end{array}$ & $\begin{array}{l}\mathrm{SD}, \mathrm{PR} \\
\mathrm{n}(\%)\end{array}$ & P-value & $\chi^{2}$ \\
\hline Study group & 71 & $42(59.2)$ & $29(40.8)$ & & \\
\hline \multicolumn{6}{|l|}{ Age (years) } \\
\hline$\leq 65$ & $44(62)$ & $24(54.5)$ & $20(45.5)$ & 0.447 & 0.578 \\
\hline$>65$ & $27(38)$ & $18(66.7)$ & $9(33.3)$ & & \\
\hline \multicolumn{6}{|l|}{ Gender } \\
\hline Male & $36(50.7)$ & $23(63.9)$ & $13(36.1)$ & 0.561 & 0.338 \\
\hline Female & $35(49.3)$ & $19(54.3)$ & $16(45.7)$ & & \\
\hline \multicolumn{6}{|l|}{ Smoking status } \\
\hline Smoker & $59(83.1)$ & $38(64.4)$ & $21(35.6)$ & 0.094 & 2.803 \\
\hline Non-smoker & $12(16.9)$ & $4(33.3)$ & $8(66.7)$ & & \\
\hline \multicolumn{6}{|l|}{ Performance status } \\
\hline$P S=0 / 1$ & $33(46.5)$ & $16(48.5)$ & $17(51.5)$ & 0.144 & 2.139 \\
\hline $\mathrm{PS}=2 / 3$ & $38(53.5)$ & $26(68.4)$ & $12(31.6)$ & & \\
\hline \multicolumn{6}{|l|}{ Histological types } \\
\hline $\begin{array}{l}\text { Adenocarcinoma and } \\
\text { adenosquamous carcinoma }\end{array}$ & $43(60.6)$ & $27(62.8)$ & $16(37.2)$ & 0.599 & 0.276 \\
\hline Other & $28(39.4)$ & $15(53.6)$ & $13(46.4)$ & & \\
\hline \multicolumn{6}{|l|}{ Response to first-line treatment } \\
\hline $\mathrm{CR}, \mathrm{PR}, \mathrm{SD}$ & $51(71.8)$ & $29(56.9)$ & $22(43.1)$ & 0.344 & 0.896 \\
\hline PD & $20(28.2)$ & $13(65)$ & $7(35)$ & & \\
\hline \multicolumn{6}{|c|}{ Time of response to first-line chemotherapy (months) } \\
\hline$\leq 12$ & $60(84.5)$ & $39(65)$ & $21(35)$ & 0.045 & 4.026 \\
\hline$>12$ & $11(15.5)$ & $3(27.3)$ & $8(72.7)$ & & \\
\hline \multicolumn{6}{|c|}{ Time from diagnosis to erlotinib treatment (months) } \\
\hline$\leq 12$ & $41(57.8)$ & $27(65.9)$ & $14(34.1)$ & 0.272 & 1.206 \\
\hline$>12$ & $30(42.2)$ & $15(50)$ & $15(50)$ & & \\
\hline \multicolumn{6}{|l|}{ Loss of body mass in 3 months } \\
\hline$\leq 5 \%$ & $48(67.6)$ & $25(52.1)$ & $23(47.9)$ & 0.135 & 2.230 \\
\hline$>5 \%$ & $23(32.4)$ & $17(73.9)$ & $6(26.1)$ & & \\
\hline \multicolumn{6}{|l|}{ Anemia } \\
\hline Yes & $54(76.1)$ & $35(64.8)$ & $19(35.2)$ & 0.148 & 2.092 \\
\hline No & $17(23.9)$ & $7(41.2)$ & $10(58.8)$ & & \\
\hline \multicolumn{6}{|l|}{ Clinical stage } \\
\hline IIIA, IIIB & $31(43.7)$ & $18(58.1)$ & $13(41.9)$ & 0.937 & 0.006 \\
\hline IV & $40(56.3)$ & $24(60)$ & $16(40)$ & & \\
\hline \multicolumn{6}{|l|}{ Previous radiotherapy } \\
\hline Yes & $31(43.7)$ & $19(61.3)$ & $12(38.7)$ & 0.937 & 0.006 \\
\hline No & $40(56.3)$ & $23(57.5)$ & $17(42.5)$ & & \\
\hline \multicolumn{6}{|l|}{ Previous surgical treatment } \\
\hline Yes & $17(23.9)$ & $8(47.1)$ & $9 \quad(52.9)$ & 0.378 & 0.775 \\
\hline No & $54(76.1)$ & $34(63)$ & $20(37)$ & & \\
\hline \multicolumn{6}{|l|}{ Line of erlotinib therapy } \\
\hline Second & $53(74.6)$ & $32(60.4)$ & $21(39.6)$ & 0.935 & 0.006 \\
\hline Third & $18(25.4)$ & $10(55.6)$ & $8(44.4)$ & & \\
\hline \multicolumn{6}{|l|}{ Erlotinib treatment-related rash } \\
\hline Yes & $15(21.1)$ & $4(26.7)$ & $11(73.3)$ & 0.009 & 6.69 \\
\hline No & $56(78.9)$ & $38(67.9)$ & $18(32.1)$ & & \\
\hline
\end{tabular}


Table III. Continued.

\begin{tabular}{|c|c|c|c|c|c|}
\hline Factor & $\begin{array}{l}\text { Total } \\
\text { n (\%) }\end{array}$ & $\begin{array}{c}\text { PD } \\
\mathrm{n}(\%)\end{array}$ & $\begin{array}{c}\mathrm{SD}, \mathrm{PR} \\
\mathrm{n}(\%)\end{array}$ & P-value & $\chi^{2}$ \\
\hline \multicolumn{6}{|l|}{ LDH serum level } \\
\hline High & $8(11.25)$ & $7(87.5)$ & $1(12.5)$ & 0.031 & 6.941 \\
\hline Normal & $19(26.75)$ & $7(36.8)$ & $12(63.2)$ & & \\
\hline Unknown & $44(62)$ & $28(63.6)$ & $16(36.4)$ & & \\
\hline \multicolumn{6}{|l|}{$E G F R$ gene amplification } \\
\hline Yes & $29(40.8)$ & $17(58.6)$ & $12(41.4)$ & 0.582 & 1.081 \\
\hline No & $11(15.5)$ & $8(72.7)$ & $3(27.3)$ & & \\
\hline Unknown & $31(43.7)$ & $17(54.8)$ & $14(45.2)$ & & \\
\hline \multicolumn{6}{|l|}{ EGFR gene mutation } \\
\hline Yes & $17(24)$ & $3(17.6)$ & $14(82.3)$ & 0.0002 & 13.76 \\
\hline No & $54(76)$ & $39(72.2)$ & $15(27.8)$ & & \\
\hline \multicolumn{6}{|l|}{ Type of EGFR gene mutation } \\
\hline Wild-type & $54(76)$ & $39(72.2)$ & $15(27.8)$ & 0.0002 & 17.403 \\
\hline Deletions in exon 19 & $12(16.9)$ & $1(8.3)$ & $11(91.7)$ & & \\
\hline L858R substitution in exon 21 & $5(7.1)$ & $2(40)$ & $3(60)$ & & \\
\hline
\end{tabular}

CR, complete response; PR, partial response; PD, progressive disease; SD, stable disease; EGFR, epidermal growth factor receptor.

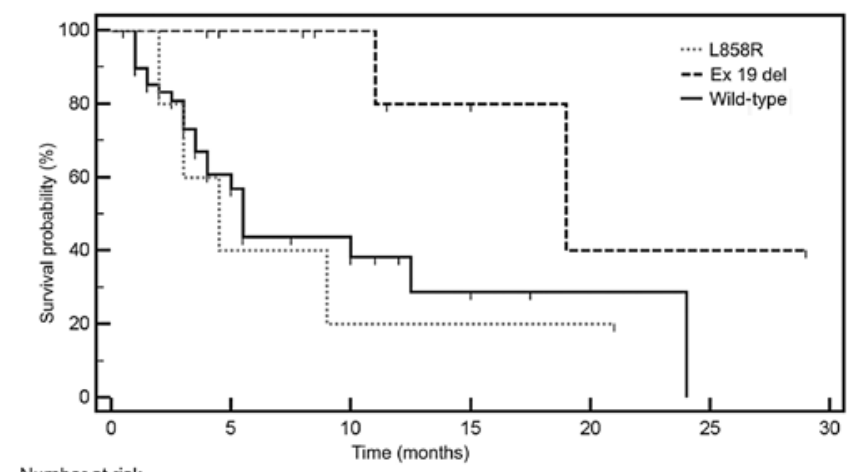

Number at risk

$\begin{array}{rrrrrrrr}\text { Wild-type } & 54 & 13 & 6 & 2 & 1 & 0 & 0 \\ \text { Ex 19 del } & 12 & 8 & 5 & 2 & 1 & 1 & 0 \\ \text { L858R } & 5 & 2 & 1 & 1 & 1 & 0 & 0\end{array}$

Figure 4. Impact of the EGFR gene mutations on overall survival of patients treated with erlotinib.

mutation and was longer in patients with deletions in exon 19 compared to patients with the L858R substitution in exon 21. Performance status, weight loss and LDH levels had weaker but significant effects on PFS in patients treated with erlotinib. Median PFS was not dependent on the degree of amplification of the EGFR gene, gender, pathology and was only slightly longer in non-smokers (Fig. 3).

Estimation of OS of erlotinib-treated patients. Median OS was 10 months. OS in patients treated with erlotinib was partially influenced by factors other than those affecting the PFS. Median OS was only insignificantly longer in patients with EGFR activating mutations than in patients without such mutations. Prolonged median OS applied only to patients with deletions in exon 19 of the EGFR gene, whereas patients with

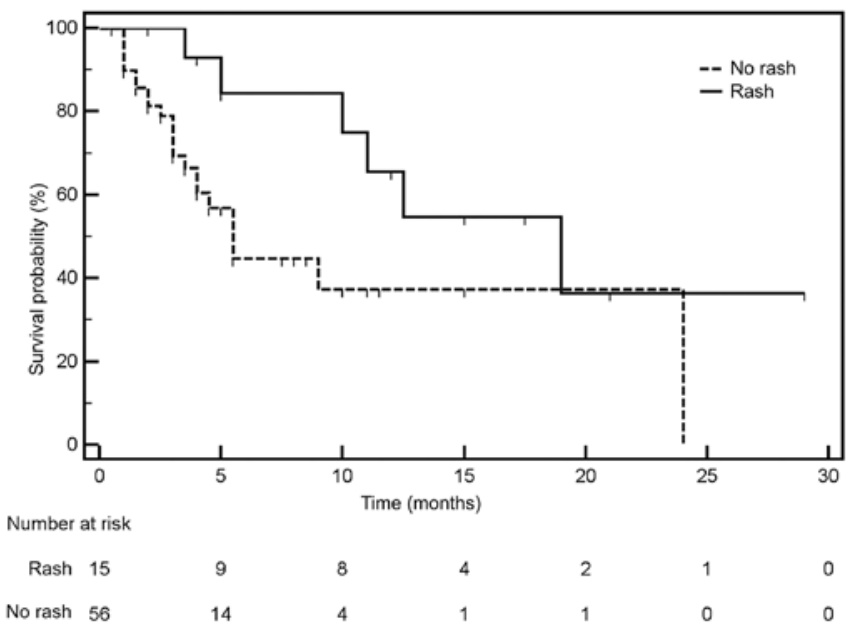

Figure 5. The relationship between the occurrence of therapy-associated rash and overall survival of patients treated with erlotinib.

L858R substitution had median OS similar to that of patients without mutations in this gene (Fig. 4). Median OS was significantly longer in patients with treatment-related rash compared to patients without this adverse effect (Fig. 5). Median OS was not affected by smoking status, gender, age, pathology and $E G F R$ gene amplification. Significant shortening of OS was associated with typical negative prognostic factors, such as poor performance status, significant loss of body mass, lack of response to first-line chemotherapy, short duration of first-line response, short follow-up time since diagnosis and LDH high serum levels.

OS and PFS are affected by multiple factors in Cox regression model. Multivariate analysis using Cox logistic regression confirmed that the strongest factors increasing risk of progres- 
Table IV. Factors affecting progression-free survival of patients treated with erlotinib in multivariate Cox logistic regression.

\begin{tabular}{lccc}
\hline Factor & $\beta$ & P-value & Hazard ratio (confidence interval) \\
\hline Absence of EGFR gene activating mutations & 1.7712 & $>0.0001$ & $5.878(2.773-12.457)$ \\
Absence of treatment-related rash & 1.5188 & 0.0002 & $4.567(2.061-10.120)$ \\
Erlotinib in the third-line therapy & 1.1965 & 0.0035 & $3.308(1.489-7.349)$ \\
Short response to first-line chemotherapy & 1.0511 & 0.0227 & $2.861(1.164-7.031)$ \\
Short time from diagnosis to the start of erlotinib treatment & 0.8365 & 0.0162 & $2.308(1.171-4.548)$ \\
Poor performance status (PS=2) & 0.8033 & 0.0078 & $2.232(1.240-4.021)$ \\
\hline
\end{tabular}

Overall model fit: $\chi^{2}=56.489 ; \mathrm{P}<0.0001$. EGFR, epidermal growth factor receptor.

Table V. Factors affecting the overall survival in patients treated with erlotinib in multivariate Cox logistic regression.

\begin{tabular}{llcc}
\hline Factor & $\beta$ & P-value & Hazard ratio (confidence interval) \\
\hline Poor performance status (PS=2) & 3.62 & $>0.0001$ & $37.344(7.912-176.256)$ \\
Absence of erlotinib-related rash & 2.7037 & 0.0002 & $14.9348(3.543-62.954)$ \\
Short response to first line chemotherapy & 2.253 & 0.0445 & $9.519(1.069-84.774)$ \\
Short period from diagnosis to start of erlotinib treatment & 2.167 & 0.0015 & $8.735(2.299-33.194)$ \\
Third line erlotinib treatment & 1.49 & 0.0135 & $4.439(1.369-14.387)$ \\
Absence of $E G F R$ gene activating mutation & 1.032 & 0.04 & $2.805(1.051-7.487)$ \\
\hline
\end{tabular}

Overall model fit: $\chi^{2}=69.381 ; \mathrm{P}<0.0001$. EGFR, epidermal growth factor receptor.

sion in patients treated with erlotinib are the absence of EGFR gene activating mutations (risk nearly 6-fold higher) and absence of treatment-related rash (risk increase 4.5-fold). These factors are closely related to the mechanism of action of TKI EGFR. The value of other factors that affect the risk of progression is associated with their traditional prognostic role, affecting the course of the disease (Table IV).

On the other hand, prognostic factors have a decisive influence on the risk of early mortality in patients treated with erlotinib. This risk is multiplied in patients with poor performance status, short response to first-line chemotherapy and short time from diagnosis to start of erlotinib. Predictive factors affecting the effectiveness of TKI EGFR also affect the risk of mortality. Although the absence of EGFR gene mutation increases the risk by only 2.8 -fold with low level of significance $(\mathrm{P}=0.04)$, the absence of a rash associated with erlotinib treatment has significant effect on the risk of mortality (Table V).

\section{Discussion}

Erlotinib was introduced for the treatment of patients with NSCLC, according to the recommendations of the FDA, on November 18, 2004 (4). The efficacy and safety of the drug was confirmed in a randomized clinical double-blind, placebo-controlled trial (BR.21). The study included 731 patients with locally advanced or metastatic NSCLC in whom standard chemotherapy had failed. Median OS in patients treated with erlotinib was 6.7 months compared to
4.7 months in the placebo group. Regardless of the presence of molecular factors, erlotinib prolonged PFS and improved quality of life compared to the best supportive care (BSC), but the objective response occurred in only $8.9 \%$ of patients (5).

Our study does not indicate that the median OS and PFS depend significantly on gender, age, tumor pathology or smoking status. Results differ from those commonly found in literature but our group was dominated by smokers or ex-smokers. Shepherd et al (5) in the BR.21 study demonstrated that the median OS is higher in non-smokers vs. past or active smokers (12.3 vs. 5.5 months, $\mathrm{P}<0.006)$, women vs. men (8.4 vs. 5.7 months, $\mathrm{P}=0.76$ ) and in patients diagnosed with adenocarcinoma vs. squamous ( 7.8 vs. 5.6 months, $\mathrm{P}=0.97$ ). The TRIBUTE study demonstrated results of treatment in non-smoking patients. OS was significantly longer (by 12.4 months) in patients who were treated with erlotinib compared to placebo (22.5 vs. 10.1 months; HR, 0.49; 95\% CI, 0.28-0.85; $\mathrm{P}=0.01)$. It should be noted that the above mentioned group of patients was dominated by younger people (average age 58 vs. 64 years), women (60 vs. 37\%), and patients diagnosed with adenocarcinoma (82 vs. 58\%) (6).

There is a clinically confirmed correlation between the occurrence of rash and response to erlotinib treatment, which is also demonstrated in this study. Petrelli et al compared the relationship between the occurrence of a rash and the results of TKI treatment based on 24 trials. They found that the presence of a rash is an important independent predictive factor for treatment with EGFR TKI, affecting OS (HR, 0.30; $\mathrm{P}<0.00001)$ and the risk of disease progression (HR, 0.50; 
Table VI. Results of clinical trials concerning erlotinib and gefitinib effectiveness in second- and third-line therapy examined at molecular level in NSCLC patients.

\begin{tabular}{|c|c|c|c|c|c|}
\hline Clinical trial & $\begin{array}{l}\text { No. of patients and } \\
\text { type of treatment }\end{array}$ & $\begin{array}{l}\text { Subgroups (only } \\
\text { patients treated } \\
\text { with TKI EGFR) }\end{array}$ & $\begin{array}{l}\mathrm{ORR}^{\mathrm{a}} \\
(\%)\end{array}$ & $\begin{array}{l}\text { Median PFS } \\
\quad \text { (months) }\end{array}$ & $\begin{array}{l}\text { Median OS } \\
\text { (months) }\end{array}$ \\
\hline IDEAL1 (10) & $\begin{array}{l}\mathrm{N}=210(50 \% \text { Asian patients }) \\
\text { - gefitinib } 250 \text { or } 500 \mathrm{mg} / \text { day }\end{array}$ & $\begin{array}{l}250 \mathrm{mg} / \text { day } \\
500 \mathrm{mg} / \text { day }\end{array}$ & $\begin{array}{c}18.4 \\
19\end{array}$ & $\begin{array}{l}2.7 \\
2.8\end{array}$ & $\begin{array}{l}7.6 \\
8.0\end{array}$ \\
\hline IDEAL2 (11) & $\begin{array}{l}\mathrm{N}=216 \text { (Caucasian patients) } \\
\text { - gefitinib } 250 \text { or } 500 \mathrm{mg} / \mathrm{day} \\
\text { after platinium compounds } \\
\text { and docetaxel }\end{array}$ & $\begin{array}{l}250 \mathrm{mg} / \text { day } \\
500 \mathrm{mg} / \text { day }\end{array}$ & $\begin{array}{c}11.8 \\
8.8\end{array}$ & $\begin{array}{l}1.9 \\
1.9\end{array}$ & $\begin{array}{l}6.5 \\
6.0\end{array}$ \\
\hline Both IDEAL1 (10) & FISH performer on & $\mathrm{FISH}+(\mathrm{n}=7)$ & 29 & 2.9 & $\mathrm{BD}$ \\
\hline IDEAL2 (11)b & $\begin{array}{l}90 \text { samples and } \\
E G F R \text { mutation analysis } \\
\text { on } 79 \text { samples }\end{array}$ & $M+(n=14)$ & 46 & 3.9 & $\mathrm{BD}$ \\
\hline INTEREST (12) & $\begin{array}{l}\mathrm{N}=729 \text { - gefitinib } 250 \mathrm{mg} / \text { day, } \\
\mathrm{N}=715 \text { - docetaxel } 75 \mathrm{mg} / \mathrm{m}^{2}\end{array}$ & $\begin{array}{l}\text { All patients } \\
\text { FISH+ }(n=77 / 157) \\
M+(n=19 / 125)\end{array}$ & $\begin{array}{c}9.1 \\
13 \\
42.1\end{array}$ & $\begin{array}{l}2.2 \\
2.5 \\
7.0\end{array}$ & $\begin{array}{r}7.6 \\
8.4 \\
14.2\end{array}$ \\
\hline ISEL (13) & $\begin{array}{l}\mathrm{N}=1129-\text { gefitinib } 250 \mathrm{mg} / \mathrm{day} \\
\mathrm{N}=563-\text { placebo }\end{array}$ & $\begin{array}{c}\text { All patients } \\
\text { FISH+ }(n=37 / 114) \\
M+(n=16 / 132)\end{array}$ & $\begin{array}{c}8 \\
16.4 \\
37.5\end{array}$ & $\begin{array}{r}3^{\mathrm{c}} \\
4.5 \\
10.8\end{array}$ & $\begin{array}{c}5.6 \\
8.3 \\
\mathrm{BD}\end{array}$ \\
\hline BR.21 (5) & $\begin{array}{l}\mathrm{N}=488-\text { erlotinib } 150 \mathrm{mg} / \text { day, } \\
\mathrm{N}=243-\text { placebo } \\
\text { (<13\% Asian patients) }\end{array}$ & $\begin{array}{l}\text { All patients } \\
\text { FISH+ }(n=61 / 159) \\
M+(n=37 / 204)\end{array}$ & $\begin{array}{l}8.9 \\
21 \\
27\end{array}$ & $\begin{array}{l}2.2 \\
\mathrm{BD} \\
\mathrm{BD}\end{array}$ & $\begin{array}{r}6.7 \\
10.5 \\
10.9\end{array}$ \\
\hline TRUST (14) & $\begin{array}{l}\mathrm{N}=4002 \text { (Caucasian) - } \\
\text { erlotinib } 150 \mathrm{mg} / \text { day }\end{array}$ & $\begin{array}{c}\text { All patient } \\
\text { FISH+ }(n=49 / 208) \\
M+(n=6 / 86)\end{array}$ & $\begin{array}{c}9.2 \\
17 \\
33.3\end{array}$ & $\begin{array}{r}3 \\
4 \\
12.7\end{array}$ & $\begin{array}{r}6.7 \\
8.6 \\
16.7\end{array}$ \\
\hline TITAN (15) & $\begin{array}{l}\mathrm{N}=203-\text { erlotinib } 150 \mathrm{mg} / \text { day } \\
\mathrm{N}=221-\text { docetaxel } \\
\text { or pemetrexed }\end{array}$ & $\begin{array}{c}\text { All patients } \\
\text { FISH+ }(n=121 / 132) \\
M+(n=8 / 83)\end{array}$ & $\begin{array}{l}7.9 \\
\mathrm{BD} \\
\mathrm{BD}\end{array}$ & $\begin{array}{l}1.5 \\
\mathrm{BD} \\
8.8\end{array}$ & $\begin{array}{r}5.3 \\
6.4 \\
19.3\end{array}$ \\
\hline
\end{tabular}

a Only patients treated with TKI EGFR. ${ }^{b}$ Molecular studies were performed retrospectively in the available diagnostic material collected at times a few years before the start of treatment. ${ }^{\mathrm{C}}$ Time to treatment failure (TTF). TKI EGFR, tyrosine kinase inhibitor of epidermal growth factor receptor; ORR, odds response rate; FISH, fluorescence in situ hybridization; M+, patients with mutation in the EGFR gene.

$\mathrm{P}<0.00001)$. In addition, objective response to treatment was significantly higher in patients who experienced cutaneous adverse effects of treatment ( $42 \%$ compared to $7 \%$ in patients without rash) (7). Tendency for cutaneous adverse effect complications in the case of erlotinib is most likely associated with $E G F R$ gene polymorphism.

With the new data on intracellular signaling pathways and their role in cancer development, molecular targets for small molecule TKI EGFR, including erlotinib, have been identified. Biomarkers which were initially analyzed included expression score of the EGFR extracellular domain and the gene number copies in tumor cells.

The increased number of EGFR gene copies was the first molecular predictive marker for TKI. There are no clear data on the impact of gene amplification on the effectiveness of gefitinib or erlotinib. Results of previous studies are controversial. Conclusions from the BR.21 study showed that patients with amplification or high polisomy of EGFR gene benefit more from treatment with erlotinib (8). Similar conclusions were presented by a group of Japanese researchers evaluating the efficacy of gefitinib in patients with EGFR gene amplification; they achieved statistically longer survival, higher objective response rate (ORR) and longer PFS compared to patients without gene amplification $(\mathrm{P}=0.014)(9)$. A number of phase III studies have been performed concerning erlotinib and gefitinib effectiveness in second- and third-line therapy of unselected NSCLC patients. However, molecular analysis in these studies was conducted retrospectively and on small groups of patients (Table VI).

The results of our analysis do not indicate EGFR gene amplification as a predictive marker for therapy. Median OS and PFS do not depend on the presence of gene amplification. Moreover, there was no correlation between EGFR gene amplification and the presence of activating mutation of $E G F R$ gene. This may be associated with FISH analysis limitations, challenges with obtaining results of diagnostic value. 
The results of first clinical trials, of low molecular weight, proved that there are populations of patients who are significantly more responsive to TKI EGFR (erlotinib and gefitinib) treatment. These are patients of predominantly Asian origin, diagnosed with adenocarcinoma, with therapy associated rash, women and never smokers. Subsequently, activating mutations in the EGFR gene responsible for this relationship were described (16-18). The presence of the mutation is currently the most important molecular factor for predicting response to TKI EGFR treatment.

The results of several phase III clinical trials with gefitinib (IPASS, JP 0056 - NEJ 002, WJTOG3405, First-Signal) in the group of patients with confirmed mutation in the EGFR gene, showed a significantly higher efficacy of gefitinib compared to chemotherapy (19-22). In the OPTIMAL study conducted among Asian patients with EGFR mutations, erlotinib therapy achieved a significant increase in response rate ( $83 \mathrm{vs.} 36 \%)$ and PFS (13.1 vs. 4.6 months) (23). In the EURTAC study, which included Caucasian patients with EGFR gene mutations the results were: $\mathrm{ORR}=58$ vs. $15 \%$; $\mathrm{PFS}=9.7$ vs. 5.2 months (24).

The presence of activating mutations in the EGFR gene was an important predictive factor for erlotinib therapy in our study group as well. Rosell et al (25) evaluated the incidence of activating mutations in the EGFR gene in 2105 Caucasian patients, of whom 350 (16.6\%) showed a mutation. Erlotinib was used as a first-line therapy in 113 patients, and as a second- or third-line therapy in 104 patients. PFS and median OS in patients with EGFR activating mutations treated with TKI EGFR were similar regardless of line of therapy (PFS, 14 months; OS, 28 months in first-line therapy and 27 months in second- and third-line therapy). Patients who had a deletion in exon 19 achieved a higher ORR compared to patients with L858R substitution ( $\mathrm{P}=0.001)$.

Although, there is a clear need for the use of TKI EGFR for second- and third-line therapy in patients with EGFR gene mutations, the use of these drugs in patients with undetected EGFR mutation remains problematic (26). In the present study, disease control was observed in $27.8 \%$ of patients with no detected $E G F R$ mutation. On the other hand, early progression was described in $17.6 \%$ of patients with activated EGFR gene mutation. The reason for this may be underestimation of $E G F R$ mutation or appearance of genetic abnormalities responsible for resistance to TKI EGFR. Therefore, careful analysis of clinical factors for qualification to molecular examination and TKI EGFR therapy as well as appropriate selection of molecular tests are required.

In conclusion, this study presents the results of secondand third-line erlotinib treatment in a group of 71 patients with advanced NSCLC. Objective response occurred in only 5 patients (7\%); all had activating mutations of EGFR and developed rash during therapy. The influence of a number of clinical and molecular factors on the efficacy of erlotinib was assessed. We concluded that detection of EGFR gene mutation is not the only factor determining the effectiveness of erlotinib in second- or third-line therapy in advanced NSCLC patients. Evaluation of molecular and clinical predictive factors in individual patients is important both from a clinical and an economic point of view, assuming similar efficacy and favorable toxicity profile of erlotinib compared to docetaxel or pemetrexed in patients with relapsed NSCLC.

\section{References}

1. Jemal A, Bray F, Center MM, et al: Global cancer statistics. CA Cancer J Clin 61: 69-90, 2011.

2. D'Addario G, Früh M, Reck M, Baumann P, Klepetko W and Felip E: Metastatic non-small-cell lung cancer: ESMO Clinical Practice Guidelines for diagnosis, treatment and follow-up. Ann Oncol 21: v116-v119, 2010.

3. Dancey $\mathbf{J}$ and Sausville EA: Issues and progress with protein kinase inhibitors for cancer treatment. Nat Rev Drug Discov 2: 296-313, 2003.

4. Cohen MH, Johnson JR, Chen YF, Sridhara R and Pazdur R: FDA drug approval summary: erlotinib (Tarceva) tablets. Oncologist 10: 461-466, 2005.

5. Shepherd FA, Rodrigues PJ, Ciuleanu T, et al: Erlotinib in previously treated non-small-cell lung cancer. N Engl J Med 353: 123-132, 2005.

6. Herbst RS, Prager D, Hermann R, et al: TRIBUTE: a phase III trial of erlotinib hydrochloride (OSI-774) combined with carboplatin and paclitaxel chemotherapy in advanced non-small-cell lung cancer. J Clin Oncol 23: 5892-5899, 2005.

7. Petrelli F, Borgonovo K, Cabiddu M, Lonati V and Barni S: Relationship between skin rash and outcome in non-small-cell lung cancer patients treated with anti-EGFR tyrosine kinase inhibitors: a literature-based meta-analysis of 24 trials. Lung Cancer 78: 8-15, 2012

8. Tsao MS, Sakurada A, Cutz JC, et al: Erlotinib in lung cancer molecular and clinical predictors of outcome. N Engl J Med 353: $133-144,2005$.

9. Takano T, Ohe Y, Sakamoto H, et al: Epidermal growth factor receptor gene mutations and increased copy numbers predict gefitinib sensitivity in patients with recurrent non small- cell lung cancer. J Clin Oncol 23: 6829-6837, 2005

10. Fukuoka M, Yano S, Giaccone G, et al: Multi-institutional randomized phase II trial of gefitinib for previously treated patients with advanced non-small-cell lung cancer (the IDEAL 1 Trial). J Clin Oncol 21: 2237-2246, 2003.

11. Kris MG, Natale RB, Herbst RS, et al: A phase II trial of ZD 1839 ('Iressa') in advanced non-small-cell lung cancer (NSCLC) patients who had failed platinum- and docetaxel-based regimens (IDEAL 2). Proc Am Soc Clin Oncol 21: 292a, 2002.

12. Kim ES, Hirsh V, Mok T, et al: Gefitinib versus docetaxel in previously treated non-small-cell lung cancer (INTEREST): a randomised phase III trial. Lancet 372: 1809-1818, 2008.

13. Thatcher N, Chang A, Parikh P, et al: Gefitinib plus best supportive care in previously treated patients with refractory advanced non-small-cell lung cancer: results from a randomized, placebo-controlled, multicentre study (Iressa Survival Evaluation in Lung Cancer). Lancet 366: 1527-1537, 2005.

14. Reck M, van Zandwijk N, Gridelli C, et al: Erlotinib in advanced non-small cell lung cancer: efficacy and safety findings of the global phase IV Tarceva Lung Cancer Survival Treatment study. J Thorac Oncol 5: 1616-1622, 2010.

15. Ciuleanu T, Stelmakh L, Cicenas S, et al: Efficacy and safety of erlotinib versus chemotherapy in second-line treatment of patients with advanced, non-small-cell lung cancer with poor prognosis (TITAN): a randomised multicentre, open-label, phase 3 study. Lancet Oncol 13: 300-308, 2012.

16. Taron M, Ichinose $\mathrm{Y}$, Rosell R, et al: Activating mutations in the tyrosine kinase domain of the epidermal growth factor receptor are associated with improved survival in gefitinib-treated chemorefractory lung adenocarcinomas. Clin Cancer Res 11: 5878-5885, 2005.

17. Endo K, Konishi A, Sasaki H, et al: Epidermal growth factor receptor gene mutation in non-small cell lung cancer using highly sensitive and fast TaqMan PCR assay. Lung Cancer 50: 375-384, 2005.

18. Paez JG, Jänne PA, Lee JC, et al: EGFR mutations in lung cancer: correlation with clinical response to gefitinib therapy. Science 304: 1497-1500, 2004.

19. Fukuoka M, Wu YL, Thongprasert S, et al: Biomarker analyses and final overall survival results from a phase III, randomized, open-label, first-line study of gefitinib versus carboplatin/ paclitaxel in clinically selected patients with advanced non-smallcell lung cancer in Asia (IPASS). J Clin Oncol 29: 2866-2874, 2011.

20. Maemondo M, Inoue A, Kobayashi K, et al: Gefitinib or chemotherapy for non-small-cell lung cancer with mutated $E G F R$. N Engl J Med 362: 2380-2388, 2010. 
21. Mitsudomi T, Morita S, Yatabe Y, et al: Gefitinib versus cisplatin plus docetaxel in patients with non-small-cell lung cancer harbouring mutations of the epidermal growth factor receptor (WJTOG3405): an open label, randomised phase 3 trial. Lancet Oncol 11: 121-128, 2010.

22. Han JY, Park K, Kim SW, et al: First-SIGNAL: first-line single-agent iressa versus gemcitabine and cisplatin trial in never-smokers with adenocarcinoma of the lung. J Clin Oncol 30: 1122-1128, 2012.

23. Zhou C, Wu YL, Chen G, et al: Erlotinib versus chemotherapy as first-line treatment for patients with advanced EGFR mutationpositive non-small-cell lung cancer (OPTIMAL, CTONG-0802): a multicentre, open-label, randomised, phase 3 study. Lancet Oncol 12: 735-742, 2011.
24. Rosell R, Carcereny E, Gervais R, et al: Erlotinib versus standard chemotherapy as first-line treatment for European patients with advanced $E G F R$ mutation-positive non-small-cell lung cancer (EURTAC): a multicentre, open-label, randomised phace 3 trial. Lancet Oncol 13: 239-246, 2012.

25. Rosell R, Moran T, Quertalt C, et al: Screening for epidermal growth factor receptor mutations in lung cancer. N Engl J Med 361: 958-967, 2009.

26. Gao H, Ding X, Wei D, et al: Erlotinib in patients with advanced non-small-cell lung cancer: a meta-analysis. Trans Lung Cancer Res 1: 129-144, 2012. 